\title{
Front Matter: Volume 11213
}

, "Front Matter: Volume 11213," Proc. SPIE 11213, Imaging, Therapeutics, and Advanced Technology in Head and Neck Surgery and Otolaryngology 2020, 1121301 (4 March 2020); doi: 10.1117/12.2569479

SPIE. Event: SPIE BiOS, 2020, San Francisco, California, United States 


\section{PROGRESS IN BIOMEDICAL OPTICS AND IMAGING

\section{Imaging, Therapeutics, and Advanced Technology in Head and Neck Surgery and Otolaryngology 2020}

Brian J. F. Wong

Justus F. llgner

Editors

1 February 2020

San Francisco, California, United States

Sponsored and Published by

SPIE

Volume 11213 
The papers in this volume were part of the technical conference cited on the cover and title page. Papers were selected and subject to review by the editors and conference program committee. Some conference presentations may not be available for publication. Additional papers and presentation recordings may be available online in the SPIE Digital Library at SPIEDigitalLibrary.org.

The papers reflect the work and thoughts of the authors and are published herein as submitted. The publisher is not responsible for the validity of the information or for any outcomes resulting from reliance thereon.

Please use the following format to cite material from these proceedings:

Author(s), "Title of Paper," in Imaging, Therapeutics, and Advanced Technology in Head and Neck Surgery and Otolaryngology 2020, edited by Brian J. F. Wong, Justus F. Ilgner, Proceedings of SPIE Vol. 11213 (SPIE, Bellingham, WA, 2019) Seven-digit Article CID Number.

ISSN: 1605-7422

ISSN: 2410-9045 (electronic)

ISBN: 9781510631892

ISBN: 9781510631908 (electronic)

Published by

SPIE

P.O. Box 10, Bellingham, Washington 98227-0010 USA

Telephone +1 3606763290 (Pacific Time) · Fax +1 3606471445

SPIE.org

Copyright (c) 2020, Society of Photo-Optical Instrumentation Engineers.

Copying of material in this book for internal or personal use, or for the internal or personal use of specific clients, beyond the fair use provisions granted by the U.S. Copyright Law is authorized by SPIE subject to payment of copying fees. The Transactional Reporting Service base fee for this volume is $\$ 21.00$ per article (or portion thereof), which should be paid directly to the Copyright Clearance Center (CCC), 222 Rosewood Drive, Danvers, MA 01923. Payment may also be made electronically through CCC Online at copyright.com. Other copying for republication, resale, advertising or promotion, or any form of systematic or multiple reproduction of any material in this book is prohibited except with permission in writing from the publisher. The CCC fee code is $1605-$ $7422 / 20 / \$ 21.00$.

Printed in the United States of America by Curran Associates, Inc., under license from SPIE.

Publication of record for individual papers is online in the SPIE Digital Library.

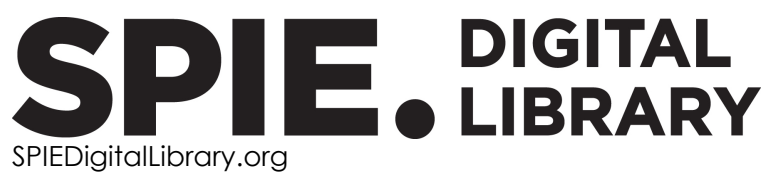

Paper Numbering: Proceedings of SPIE follow an e-First publication model. A unique citation identifier (CID) number is assigned to each article at the time of publication. Utilization of CIDs allows articles to be fully citable as soon as they are published online, and connects the same identifier to all online and print versions of the publication. SPIE uses a seven-digit CID article numbering system structured as follows:

- The first five digits correspond to the SPIE volume number.

- The last two digits indicate publication order within the volume using a Base 36 numbering system employing both numerals and letters. These two-number sets start with $00,01,02,03,04$, 05, 06, 07, 08, 09, 0A, OB ... 0Z, followed by 10-1Z, 20-2Z, etc. The CID Number appears on each page of the manuscript. 


\title{
Contents
}

\author{
$\checkmark \quad$ Authors \\ vii Conference Committee
}

FROM BENCH TO BEDSIDE: OPTICAL DIAGNOSTIC TECHNIQUES FOR MALIGNANT AND PREMALIGNANT LESIONS OF THE ORAL CAVITY

1121305 Serum Raman spectroscopy: evaluation in hamster buccal pouch models [11213-6]

1121307 Raman microspectroscopy of oral mucosa: exploring Raman mapping in experimental carcinogenesis [1 1213-8]

1121308 Development of a new polarized hyperspectral imaging microscope [11213-9]

1121309 Design and validation of an intraoperative autofluorescence lifetime imaging device [11213-18]

CLINICAL TRANSLATION OF CONFOCAL OPTICS AND SURGICAL USE OF LASER TECHNOLOGY

$11213 \mathrm{OD}$ Comparative in-vitro investigations on the cutting quality of the $\mathrm{CO}_{2}$ laser and the diode pumped Er:YAG laser [1 1213-11]

COMBINING NOVEL IMAGING TECHNOLOGY FOR FUNCTIONAL ASSESSMENT AND THERAPY GUIDANCE IN UPPER AND LOWER AIRWAYS

$112130 \mathrm{~J}$ Design of a novel MEMS based laser scanning laryngoscope to combine high precision laser cuts with simultaneous $\mathrm{MHz}$ OCT and stereo camera feedback [1 1213-17]

11213 OK Differentiation of tumors of the upper respiratory tract using optical metabolic imaging [11213-20] 
Proc. of SPIE Vol. 11213 1121301-4 Downloaded From: https://www.spiedigitallibrary.org/conference-proceedings-of-spie on 25 Apr 2023
Terms of Use: https://www.spiedigitallibrary.org/terms-of-use 


\section{Authors}

Numbers in the index correspond to the last two digits of the seven-digit citation identifier (CID) article numbering system used in Proceedings of SPIE. The first five digits reflect the volume number. Base 36 numbering is employed for the last two digits and indicates the order of articles within the volume. Numbers start with 00, 01, 02, 03, 04, 05, 06, 07, 08, 09, 0A, 0B...0Z, followed by 10-12, 20-2Z, etc.

Betz, Christian, OK

Dogan, Volkan, OK

Dormer, James, 08

Eggert, Dennis, OK

Fei, Baowei, 08

Gaertner, David, OK

Halicek, Martin, 08

Heisterkamp, Alexander, 0J

Hole, Arti, 05, 07

$\mathrm{Hu}$, Yong, 09

Huang, Shan, 09

Ihler, Sontje, 0J

Ingle, Arvind, 05, 07

Jadhav, Priyanka A., 05

Kumar, Piyush, 07

Laves, Max-Heinrich, 0J

Ma, Ling, 08

Moon, Andy S., 09

Murali Krishna, C., 05, 07

Napier, James W., OJ

Neu, Walter, OJ

Pansare, Kshama, 05

Pellionisz, Peter, 09

Reins, Elisabeth, OD

Sawant, Prajakta N., 05

Schuler, Patrick J., OD

Singh, Sourav Raj, 05

St. John, Maie, 09

Stafsudd, Oscar, 09

Stock, Karl, OD

Vaswani, Heero, 05

Wurm, Holger, OD

Zabic, Miroslav, OJ

Zhou, Ximing, 08 
Proc. of SPIE Vol. 11213 1121301-6 Downloaded From: https://www.spiedigitallibrary.org/conference-proceedings-of-spie on 25 Apr 2023
Terms of Use: https://www.spiedigitallibrary.org/terms-of-use 


\title{
Conference Committee
}

\author{
Symposium Chairs
}

Jennifer K. Barton, The University of Arizona (United States)

Wolfgang Drexler, Medizinische Universität Wien (Austria)

Program Track Chairs

Brian Jet-Fei Wong, Beckman Laser Institute and Medical Clinic,

University of California, Irvine (United States)

Eva Sevick, The University of Texas Health Science Center at Houston

(United States)

\section{Conference Chairs}

Brian Jet-Fei Wong, Beckman Laser Institute and Medical Clinic,

University of California, Irvine (United States)

Justus F. Ilgner, Uniklinik RWTH Aachen (Germany)

Conference Program Committee

Henricus J. C. M. Sterenborg, Netherlands Cancer Institute, Universiteit Medisch Centrum Amsterdam AMC (Netherlands)

Milind Rajadhyaksha, Memorial Sloan-Kettering Cancer Center (United States)

Javier A. Jo, Texas A\&M University (United States)

Amy L. Oldenburg, The University of North Carolina at Chapel Hill (United States)

Maie A. St. John, The Henry Samueli School of Engineering (United States)

\section{Session Chairs}

1 Functional Diagnostic Technologies and Quality Assurance in Tympanic Membrane Reconstruction

Brian Jet-Fei Wong, Beckman Laser Institute and Medical Clinic, University of California, Irvine (United States)

2 OCT and Related Imaging Techniques for Diagnostics and Therapy Guidance for the Inner Ear

Justus F. Ilgner, Uniklinik RWTH Aachen (Germany) 
3 From Bench to Bedside: Optical Diagnostic Techniques for Malignant and Pre-malignant Lesions of the Oral Cavity

Brian Jet-Fei Wong, Beckman Laser Institute and Medical Clinic, University of California, Irvine (United States)

4 Clinical Translation of Confocal Optics and Surgical use of Laser Technology

Justus F. Ilgner, Uniklinik RWTH Aachen (Germany)

5 Combining Novel Imaging Technology for Functional Assessment and Therapy Guidance in Upper and Lower Airways

Brian Jet-Fei Wong, Beckman Laser Institute and Medical Clinic, University of California, Irvine (United States) 